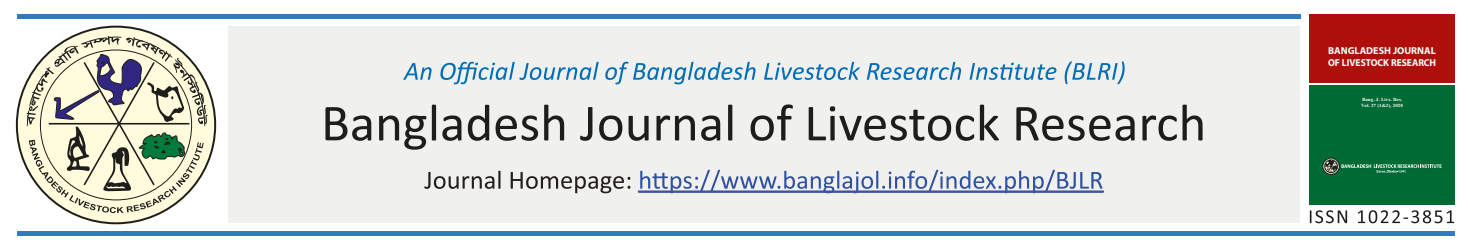

\title{
A comparative economic study on improved and non-improved native chicken practices in some selected areas of Bangladesh
}

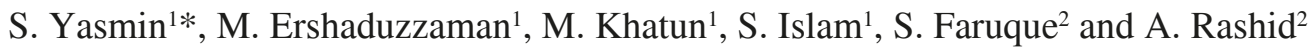 \\ ${ }^{1}$ Socioeconomic Research Division, Bangladesh Livestock Research Institute, Savar, Dhaka \\ 1341, Bangladesh. \\ ${ }^{2}$ Poultry Production Research Division, Bangladesh Livestock Research Institute, Savar, \\ Dhaka 1341, Bangladesh.
}

\begin{abstract}
Native chickens are important for the rural poor women and marginalized section for subsidiary income and safe nutrition. Considering that views, the study were conducted taking objectives is assessing the profitability of native chicken and to find the livelihood status of native chicken farmers. The study areas were selected from six districts, namely, Joypurhat Sadar under Joypurhat, Dinajpur Sadar under Dinajpur, Dumoria under Khulna, Kotalipara under Gopalgonj, Nokla under Sherpur and Sonagazi under Feni district on the basis of improved native chickens project implementation areas. The selected areas were consisted of 30 treatment groups and 30 control groups from each upazila. The total sample size was 360 $(\mathrm{P} / \mathrm{H})$. In the case of profitability, the treatment group earned BDT 3,450 per 10 birds per annum followed by control group earned BDT 2,476. The BCR was found 2.04 and 1.45, respectively for treatment and control group. It was evident that treatment group produced 60 native chickens annually and on the other hand, control group produced 30 native chickens. For control group, labour cost occupied 32 percent and the feed cost captured 23 percent. On the other hand, for treatment group, feed cost occupied 34 percent and the labour cost was 38 percent. Fifty percent farmers opined that they reared native chicken for additional family income followed by 37 percent home consumption, 9 percent ceremonies and 4 percent creating employment opportunity. Rearing of native chicken entirely depends on women's decision but the usage of money is controlled by women and men. It was found that women dominated most activities in rearing native chicken. Based on the result of the study, 100 percent women was the decision maker for rearing native chicken in both groups. Decision on selling of native chicken made by women was 92.15 percent in treatment group and 73.28 percent in control group. Money received from native chicken was also controlled 78.26 percent in treatment group and 51.57 percent in control group by women. Lack of access to livestock extension service, bad eggs quality, access to credit also was the challenges for native chicken farmers covering 7 percent, 4 percent and 4 percent, respectively. From this study, it was clear that rearing native chicken farming brought positive changes in economic, social and specially women empowerment indicators.
\end{abstract}

Key words: Native chicken, Profitability and Women empowerment

Bang. J. Livs. Res. Vol. 27 (1\&2), 2020: P. 24-38. https://doi.org/10.3329/bjlr.v27i1.55167

\section{Introduction}

Wide variety of birds of several species is called "Poultry". Poultry includes chickens, ducks, turkeys, geese, swans, pigeons, quail

*Corresponding author: sabina.bau020@gmail.com 
and other game birds. Native chickens are typically raised in the backyards of rural households. They are commonly grown in small numbers of up to about 24 hens for egg production. Some farmers raise native chickens for meat, barter, or sale as an additional source of income for the household. Improved native chicken is one of them which can be easily reared for meat and egg purposes as well as selling purposes. Income and capital formation of rural $\mathrm{H} / \mathrm{H}$ partially depends on native chicken rearing. Bangladesh is an agrarian country having small territory and large number of population. Its economy mainly depends on agriculture. Almost 75 per cent people directly depend on agriculture and 80 per cent people live in village. In financial year 2017-18, Bangladesh produced 2821.45 lakh chickens (BBS, 2018) which is the major sources of cheap protein for the majority of people. But the demand is growing high day after day. Native chickens are playing an important role for the rural economy in most of the developing country like Bangladesh. It has a remarkable contribution for the rural poor and marginalized section of the people with respect to their subsidiary income and also provides them with nutritious chicken egg and meat for their own consumption. Poultry production especially native chicken provides maximum return with minimum expense. It has a great prospect to swell poultry production in the country. Research on meat production is a global demand. As poultry is a fast growing livestock sub-sector, it might take the challenge to meet up the thrust for meat demand. The outlook for the Bangladesh Native Chicken industry appears optimistic because the demand for chicken products is expected to increase, along with population and income growth. The study was aimed to determine the profitability for semi intensive native chicken farming and to determine the factors influence it. The native chicken which is usually raised in the rural area has much potential to support the national meat consumption because of the taste and quality of the meat (Ajayi et al., 2012). This factor have made native chicken meat has a primacies price. The price is to be stable and even going up, thus it makes the native chicken farming a good business enterprise for people in rural areas to augment their income. It contributes significantly to the welfare of the population of both household and rationed levels by meeting human needs for dietary animal protein supply; providing income to farmers through sale of meat and egg; using the by-product wastes of chicken poultry as feed for the fish farming; expanding more job opportunities for the unemployed people and alleviating poverty in the shortest period of time (Uddin et al. 2013). Overall, the annual average growth in poultry production from 2009-10 to 2018-19 was $2.7 \%$ (BER, 2019).

Different types of native chicken are reared by the rural households in our country. Improved native chickens play an integral role in smallholder farming systems. The small holder chicken sector is traditionally based on extensive free range systems where the birds find most of their feed through scavenging. Small farming families, landless laborers and people with income below the poverty line rear chickens with low inputs and harvest the benefits like egg and meat via scavenged feed resources. They are used to meet social, economic and cultural needs of households. Native chickens serve as an important source of 
animal protein to the rural poor. Households often sell chickens to generate cash. Unlike other livestock species particularly cattle, chickens are accessible even to the poor and landless households. So rearing native chicken can improve the livelihood status, social status as well as income of the native chicken farmers. The overall objectives of the study was there for to estimate the profitability from native chicken production and measure resource we efficiency of the relevant factors. The study had the following specific objectives: (a) To assess the profitability of native chicken; (b) To find the livelihood status of native chicken farmers and (c) To suggest some policy guideline arising from the findings.

\section{Materials and Methods}

\section{Study design}

The design of any survey mainly depends on the aims and objectives of the study and it is again dependent on the availability of necessary resources, materials and time. Data collection is a necessary pre-requisite for any farm management research study. There are several methods for collection of necessary data of which survey method is one of them. Survey method is more advantageous than other methods of data collection. This method was preferred considering the limitation of time, money and facilities available. The word survey refers to a method of study in which an overall picture of a given universe is

obtained by a systematic collection of all available data on the subject. Survey methods has its advantage over other methods in that it does not require highly trained personnel and sophisticated equipment as may be needed by other methods.
The main shortcoming of the survey method is that the researcher has to rely upon the memory of the farmers. To overcome this, repeated visits were made to collect data from the study area and the questions were asked in such a manner that farmers could answer from their memory. Methodology deserves a very careful consideration in any scientific research. The methodology of the present study involved the following steps:

\section{Selection of the study area}

Study areas were selected from six districts namely Joypurhat, Dinajpur, Khulna, Gopalgonj, Sherpur and Feni of Bangladesh were selected for the study on the basis of native chicken density. From each district at least one Upazila and several villages under that upzilla were selected purposively and the study location considered as the concentration of native chicken density.

\section{Sampling technique \& Sample Size}

Purposive sampling technique was followed for selecting the respondents. The samples are consisted of 360 farmers of which 30 treatment groups \& 30 control group from each upazila.

\section{Period of the study}

Field survey method was conducted to collect primary data from 15 December, 2017 to 25 March, 2018. Data was collected from the respondents by used structured interview schedule and conducting FGD (Focus Group Discussion) for group information.

\section{Preparation of the survey schedule}

In conformity with the objectives of the study, a preliminary survey questionnaire 
Table 1. Sample distribution of native chicken farmers

\begin{tabular}{lccc}
\hline \multirow{2}{*}{ Districts } & \multicolumn{2}{c}{ Sample Size of Native chicken } & \multirow{2}{*}{ Total } \\
\cline { 2 - 3 } & Treatment group & Control group & \\
\hline Joypurhat & 30 & 30 & 60 \\
Dinajpur & 30 & 30 & 60 \\
Khulna & 30 & 30 & 60 \\
Gopalgong & 30 & 30 & 60 \\
Sherpur & 30 & 30 & 60 \\
Feni & 30 & 30 & 60 \\
Total & $\mathbf{1 8 0}$ & $\mathbf{1 8 0}$ & $\mathbf{3 6 0}$ \\
\hline
\end{tabular}

was designed for recording data from the farmers. After pre-testing the questionnaire, necessary corrections, modifications and adjustments were made. The questionnaire was then finalized and questions were arranged in logical sequences so that the farmers could answer the questions easily.

\section{Collection of data}

After development of the final schedule face-to-face interviews were conducted by the researcher herself and some trained enumerators for collection of primary data from the farmers, mostly at the time when they had little works at hand. Before going to make an actual interview, a brief information about the aims and objectives of the present study was clearly explained to the operating farmers and questions were asked systematically in a very simple manner and the information supplied was directly recorded on the interview schedule. It was verified by further visiting to the farmers for fulfilling the lack of information.
In order to minimize errors, data were collected in local units. However, these local units were later converted into standard units. The secondary data were collected from the Bangladesh Bureau of Statistics (BBS), Population Census reports, Economic Review report, the daily newspapers, DAE, published and unpublished articles, etc.

\section{Data editing and coding}

Data editing and coding were other vital phases of the survey, which was indispensable for data processing. It should be completed before data processing. In case of this survey, coding had been done along with questionnaire development so that the enumerator could easily and accurately mark the right answers. Data editing referred to the activity of checking and cleaning data that had already been collected from the field. 


\section{Data processing}

Data processing involved many steps that were very important because it affected survey results according to the involved steps. During data processing following steps had been taken according to Data entry, Appending and Merging files, Data validation (further computer checking, editing, and imputation), Final decision on errors, Completion of data processing and generation of data files, Final documentations, Conversion of data files to another software, Storage of all files.

\section{Data preservation}

After completion of processing, the data had been converted to Microsoft Excel format in order to have the print out. Both original and new format had been preserved. The questionnaires had also been filed for safe storage.

\section{Procedure for computation of costs and returns}

\section{Feed cost}

Feed is the most important input for poultry production in terms of cost, and the availability of low-priced, high-quality feeds is critical if poultry production is to remain competitive and continue to grow to meet the demand for animal protein. Cost of feed included readymade feed, rice polish, wheat bran, crushed maize, fish meal, soybean, salt, home consumable rice, vitamins, minerals etc. The purchased balanced feeds were valued according to the average prices actually paid by the owners of the chickens.

\section{Beginning stock/Day old chick cost}

At the beginning of a particular time, how many chickens the farmers had and the average price of those chickens were calculated as beginning stock. If a farmer start with new chicks then that cost were estimated at the prevailing market price according to their size.

\section{Cost of human labor}

Human labor was one of the most important inputs used in rearing native chicken. In this study, human labor was classified into family labor and hired labor. Family labor included the farmer himself, the adult males and females as well as children of a farmer's family and permanent labor appointed by him. The cost of hired labor was calculated at the wage rate actually paid by the farmers. In this study human labor was measured in terms of man-days, which usually consists of 8 hours of works, by an adult man. To standardize labor hours or man-days required for different operations, all labor units were converted into an equivalent. This was performed as follows (Yang, 1965). 1 adult man $=1.5$ adult woman $=2$ children.

\section{Treatment cost}

The major components of the veterinary expense were vaccine, medicine and additive cost. Total medicine costs were calculated by taking into account real cost incurred on the above items

Electricity cost

Electricity is needed for maintaining temperature of inside the native chicken house or protecting the birds for hot and cold climate.

\section{Litter cost}

Good quality litter is essentially required for rearing native chicken in open type houses 
in the climatic condition of Bangladesh. Litter includes wood shaving, sugarcane bagasse, rice husks etc. Bangladesh largely depends on rice husk as litters.

\section{Transportation cost}

The transportation cost of native chicken farmers included expenses on transportation for purchasing day old chicks, feed collection, litter collection, medicine collection, selling of eggs and chickens etc.

\section{Housing cost}

Maximum chicken houses were tin-shed with wooden or bamboo frame. In the present study, housing cost was calculated by applying straight line depreciation method. In this method, the depreciation during each period is same. The amount of depreciation to be charged during a year is worked out as follows: Depreciation = (Original value- Salvage value)/ Life of the house.

\section{Interest on operating capital}

Interest on operating capital was calculated by taking into account the cost incurred for all the field operations. The formula was used as follows:

\section{Analytical Techniques Tabular form}

Tabular technique was commonly followed to find out the crude association or differences between variables and outputs. Tabular technique is a well-known and widely used technique to show the result of farm management study because it is simple, convenient and very easy to understand. The data and information so collected were recorded to tabular form which included classification of tables into meaningful results by some statistical measures like the sum, average, percentage etc. to show the relationship between/among the selected variables. Tabular analysis was done to address the first three objectives of the study. On the other hand, statistical analysis was employed to assess the rest of the objectives of the study. Gross return was calculated by multiplying the total volume of output by the average price in the harvesting period. The following equation was used to estimate the gross return (GR):

Where,

$$
\mathrm{GR}_{\mathrm{i}}=\sum \mathrm{Q}_{\mathrm{mi}} \mathrm{P}_{\mathrm{mi}}
$$

$\mathrm{GR}_{\mathrm{i}}=$ Gross return from $\mathrm{i}^{\text {th }}$ product

(Tk/acre); $\mathrm{Q}_{\mathrm{mi}}=$ Quantity of the $\mathrm{i}^{\text {th }}$ product ( $\mathrm{kg} / \mathrm{acre})$;

$\mathrm{Pm}_{\mathrm{i}}=$ Average price of the $\mathrm{i}^{\text {th }}$ product

$(\mathrm{Tk} / \mathrm{kg}) ; \mathrm{i}=1,2,3 \ldots \mathrm{n}$

Net return analysis considered fixed cost; land use cost, interest on operating cost etc. Net return was calculated by deducting all costs (variable and fixed) from gross return.

$$
\text { Net return }=\text { GR }- \text { TC }
$$

Where, $\mathrm{TC}=$ Total fixed cost + Total variable cost Benefit Cost Ratio (BCR) was calculated by dividing total cost by gross return.

$$
\mathrm{BCR}=\mathrm{GR} / \mathrm{TC}
$$

\section{Results and Discussion}

\section{Socio-economic characteristics of the sample farmers}

The farmers in rural Bangladesh are placed in different socio-economic settings. The socio-economic characteristics of the selected farmers were not identical rather there were wide range of variations in their socio-economic position. Hence, it was not possible to collect all the information about their socio-economic settings. For the present 
study, the following variables such as, age, level of education, experience of agriculture, experience of floating agriculture, family size, Average farm size have been taken into account. A brief description of these variables is presented below Age of the respondents is an important factor in involvement in any income generating activity. In this study we found the average age of the improved native chicken farmers of rearing native chicken of control farmer was 15 years. Family size shows the availability of the family labor for productivity and other income generation activities. Here the average number of family members of Treatment farmers was 4.07 where the average number of family members of control farmers was 4.12.

\section{Average farm size}

Land is the most important asset for farmer

Table 2. Socio-economic characteristics of the sample farmers on average

\begin{tabular}{lcc}
\hline Variables & Treatment & Control \\
\hline Age (Year) & 36.18 & 32.93 \\
Education (Year) & 5.08 & 5.23 \\
Experience of rearing native chicken ( Year) & 16 & 15 \\
Family size (Number) & 4.07 & 4.12 \\
\hline
\end{tabular}

Source: Field survey, 2018.

(Treatment) was 36.18 years, on the other hand, the average age of village chicken (control) farmers' was 32.93 years. Education was considered as the key factor for transforming technology. Education was defined as the ability of an individual aged above 6 years to read and write or formal education received up-to certain standard. Here the average education year of Treatment farmer was 5.08 years where the average education year of control farmer was 5.23 years.

Experience of rearing native chicken is considered as one of the key variables to increase productivity by the farmers. In this study, the average year of experience of rearing native chicken, Treatment 1 farmer was 16 years where the average year of experience household. Land was used for producing diversified crops and productive enterprises. According to Yang (1995) "Farm size is measured by the entire land area operated by the operator." As most of the respondents were small farmers and those few remaining of them fell under the category of medium or large farmers. They had their total land size fragmented into a number of small sized lands and homestead area was put out. It was computed by adding the area of land owned, rented in and mortgaged in farm from others and subtracting the area rented out and mortgaged out to others. Thus, the farm size was measured by using the following formula: Farm size $=$ Homestead area + Own cultivated land + Rented/mortgaged/leased in + Area under pond + Pasture land Rented/ mortgaged/leased out (Uddin et al. 2013) 
Table 3 reveals that the average homestead area of improved native chicken farmers (Treatment) and the village chicken farmers (Control) stood at 12.23 decimals and 9.84 decimals, respectively; the average own cultivable land of improved native chicken farmers (Treatment) and the village chicken farmers (Control) stood at 35.58 decimals and 34.25 decimals, respectively; while average
Feed cost

Feed cost is the most important and major cost item for rearing native chicken. It was the largest cost item of rearing native chicken though the maximum chickens were scavenging. In this study the average feed cost per year for 10 birds was calculated. Table 4 shows that the average feed cost per year for 10 birds for improved native chicken

Table 3. Average size of the land holding of the sample farmers

\begin{tabular}{ccc}
\hline Land category & Treatment (decimal) & Control (decimal) \\
\hline Homestead area & 12.23 & 9.84 \\
Pond & 4.16 & 5.85 \\
Own cultivable land & 35.58 & 34.25 \\
Leased in & 21.14 & 19.04 \\
Leased out & 8.85 & 8.14 \\
Farm size & 64.26 & 60.84
\end{tabular}

leased in land size of improved native chicken farmers (Treatment) and the village chicken farmers (Control) stood at 21.14 decimals and 19.04 decimals respectively and the average leased out land size of improved native chicken farmers (Treatment) and the village chicken farmers (Control) stood at 8.85 decimals and 8.14 decimals, respectively. The average farm size of improved native chicken farmers (Treatment) and the village chicken farmers stood at 64.26 decimals and 60.84 decimals, respectively in the study area.

\section{Comparative Profitability Analysis of improved native chicken (Treatment) and village chicken (Control) Cost of rearing native chicken}

farmers (Treatment) was Tk 650 covering 34.4 percent of total cost. On the other hand the average feed cost per year for 10 birds for village chicken farmers (Control) was Tk 275 covering 23 percent of total cost.

Beginning stock/ Day old chick cost

Beginning stock cost was another crucial cost item for rearing native chicken. It appears from Table 4 that beginning stock value for 10 birds for improved native chicken farmers (Treatment) was Tk 180 covering 9.5 percent of total cost where the average feed cost per year for 10 birds for village chicken farmers (Control) was Tk 90 covering 7.5 percent of total cost. 


\section{Treatment cost}

Vaccine, medicine etc. were the major components of treatment cost. Table 4 show that the average treatment cost per year for 10 birds for improved native chicken farmers (Treatment) was Tk 94 covering 5 percent of total cost. On the other hand the average feed cost per year for 10 birds for village chicken farmers (Control) was Tk 96 covering 8 percent of total cost.

\section{Electricity cost}

Impact of electricity cost of chicken for scavenging system is negligible. Table 4 revealed that the electricity cost per year for 10 birds for improved native chicken farmers (Treatment) was Tk 2 covering 0.1 percent of total cost but the village chicken farmers didn't use electricity for their chickens.

\section{Litter cost}

Rearing native chicken in scavenging system the litter has few impacts. Farmers didn't use litters for rearing native chicken that is why we neglected to calculate that litter cost.

\section{Transportation cost}

It is evident from Table 4 that transportation cost per year for 10 birds for improved native chicken farmers (Treatment) was Tk 12 covering 0.6 percent of total cost. On the other hand, the average transportation cost per year for 10 birds for village chicken farmers (Control) was Tk 22 covering 1.8 percent of total cost.

\section{Interest on operating capital}

It is evident from Table 4 that interest on operating capital per year for 10 birds for improved native chicken farmers
(Treatment) was Tk 94 covering 5 percent of total cost. On the other hand, the average transportation cost per year for 10 birds for village chicken farmers (Control) was Tk 41 covering 3.4 percent of total cost.

\section{Cost of human labor}

Labor cost is an important component for rearing native chicken. Labor was mainly used for feeding, cleaning of house, medical care, transporting, making house for chicken, selling of chicken etc. It is revealed from Table 4 that the average cost of labor per year for 10 birds of improved native chicken farmers (Treatment) was Tk 723 covering 38.2 percent of total cost. On the other hand, the average feed cost per year for 10 birds of native chicken farmers (Control) was Tk 381 covering 31.9 percent of total cost.

\section{Housing cost}

A house is required for native chicken to protect them from sunshine, rainfall, cold weather, storms, wild animals etc. Table 4 shows that average housing cost per year for 10 birds of improved native chicken farmers (Treatment) was Tk 129 covering 6.8 percent of total cost. On the other hand, the average housing cost per year for 10 birds of village chicken farmers (Control) was Tk 72 covering 6 percent of total cost.

\section{Total cost (TC)}

In rearing native chicken, total costs were calculated on the basis of full cost basis. Table 4 shows that total cost per year for 10 birds of improved native chicken farmers (Treatment) was Tk 1891. On the other hand, the average housing cost per year for 10 birds of village chicken farmers (Control) was Tk 1194. 


\section{Returns from rearing native chicken}

Gross return

To determine the gross return from rearing native chicken, it was necessary to calculate of village chicken farmers (Control) was Tk 1276.

Net return (NR)

Net return on total cost was arrived at by deducting all the costs from the gross return.

Table 4. Average cost involved in rearing improved native chicken (Treatment) and village chicken (Control)

10 birds/year

\begin{tabular}{l|c|c|c|c}
\hline Cost items & Treatment (Tk) & Percent (\%) & Control (Tk) & Percent (\%) \\
\hline Variable cost & 650 & 34.4 & 275 & 23.0 \\
\hline Feed cost & 180 & 9.5 & 90 & 7.5 \\
\hline Beginning stock value & 94 & 5.0 & 96 & 8.0 \\
\hline Medicine and vaccine & 2 & 0.1 & 0 & 0.0 \\
\hline Electricity & 12 & 0.6 & 22 & 1.8 \\
\hline Transportation & 7 & 0.4 & 17 & 1.4 \\
\hline Repairing & 94 & 5.0 & 41 & 3.4 \\
\hline Interest on operating capital & 1039 & 54.9 & 541 & 45.3 \\
\hline A. Total variable cost & 723 & 38.2 & 381 & 31.9 \\
\hline Fixed cost & 129 & 6.8 & 72 & 6.0 \\
\hline Labour & 852 & 45.1 & 653 & 54.7 \\
\hline Housing & 1891 & 100.0 & 1194 & 100.0 \\
\hline B. Total fixed cost & \multicolumn{5}{|l}{} \\
\hline C. Total cost (A+B) & \multicolumn{5}{|l}{} \\
\hline
\end{tabular}

Source: Field survey, 2018.

all the returns coming from selling chicken and eggs, consumed chicken and eggs, gift out of chicken and eggs and closing stock. Table 5 revealed that gross return per year for 10 birds of improved native chicken farmers (Treatment) was Tk 3774. On the other hand, gross return per year for 10 birds of village chicken farmers (Control) was Tk 1276.

\section{Gross margin (GM)}

Gross Margin is defined as the difference between gross return and variable cost. It is evident from Table 5 that gross margin per year for 10 birds of improved native chicken farmers (Treatment) were Tk 2735. On the other hand, gross return per year for 10 birds
Table 5 reveals that net return per year for 10 birds of improved native chicken farmers (Treatment) was Tk 1883. On the other hand, net return per year for 10 birds of village chicken farmers (Control) was Tk 623.

Benefit cost ratio (BCR)

Benefit cost ratio implies return per Taka invested. It helps to analyze the financial efficiency of the farmer. It is evident from the study that the benefit cost ratio per year for 10 birds of improved native chicken farmers (Treatment) was 2.00. On the other hand, benefit cost ratio per year for 10 birds of village chicken farmers (Control) was 1.52. 
Role of women in native chicken production and ownership

Native chicken production in most developing countries is based mainly on scavenging system and rural women and children traditionally play an important management role. They are generally in charge of most chicken husbandry practices, since small-scale animal production does not require heavy manual labor. According to Bradley (1992), Native chicken production could be easily managed within homesteads and the management has been associated with women for various historical and social factors.
Table 6 revealed that women dominated most activities in rearing native chicken. Based on the result of the study, 100 percent women was the decision maker for rearing native chicken in both groups. Decision on selling of native chicken made by women was 92.15 percent in treatment group and 73.28 percent in control group. Money received from native chicken was also controlled 78.26 percent in treatment group and 51.57 percent in control group by women.

Table 5. Average revenue from rearing improved native chicken (Treatment) and village chicken (Control)

\begin{tabular}{l|c|c|c|c}
\hline \multicolumn{3}{|c|}{} & \multicolumn{3}{c}{10 birds/year } \\
\hline Income flow & $\begin{array}{c}\text { Treatment } \\
(\mathrm{Tk})\end{array}$ & Percent (\%) & $\begin{array}{c}\text { Control } \\
(\mathrm{Tk})\end{array}$ & $\begin{array}{c}\text { Percent } \\
(\%)\end{array}$ \\
\hline Chicken sold & 1513 & 40.1 & 800 & 44 \\
\hline Eggs sold & 795 & 21.1 & 150 & 7 \\
\hline Family Consumption of Chicken & 488 & 12.9 & 450 & 27 \\
\hline Family Con. of Eggs & 485 & 12.9 & 279 & 16 \\
\hline Gift Out Chicken & 49 & 1.3 & 43 & 2 \\
\hline Gift out eggs & 29 & 0.8 & 0 & 0 \\
\hline Closing stock & 415 & 11.0 & 95 & 4 \\
\hline D. Total Revenue & 3774 & 100.0 & 1817 & 100 \\
\hline E. Gross margin (D -A) & \multicolumn{2}{|c|}{2735} & \multicolumn{2}{c}{1276} \\
\hline F. Net Return (D -C) & \multicolumn{2}{|c|}{1883} \\
\hline G. BCR (D/C) & 2.00 & \multicolumn{2}{c}{1.52} \\
\hline
\end{tabular}

Source: Field survey, 2018.

Table 6. Women empowerment

\begin{tabular}{l|c|c|c|c|c|c}
\hline \multirow{2}{*}{ Decisions } & \multicolumn{3}{c|}{ Treatment } & \multicolumn{3}{c}{ Control } \\
\cline { 2 - 7 } & Man & Women & Both & Man & Women & Both \\
\hline Decision make for rearing native chicken & - & 100 & - & - & 100 & - \\
\hline Decision make for selling native chicken & 0.95 & 92.15 & 6.80 & 6.58 & 78.26 & 15.16 \\
\hline $\begin{array}{l}\text { Control of money receive from native } \\
\text { chicken }\end{array}$ & 23.05 & 73.28 & 3.67 & 11.49 & 51.57 & 8.94 \\
\hline
\end{tabular}

Source: Field survey, 2018. 
Challenges and farmers suggestion in rearing native chicken

Farmers in the study areas were faced some problems in rearing native chicken. Some major problems of rearing native chicken by all the sample farmers and some recommendation to solve the problems are presented here:

\section{Period of the study}

Field survey method was conducted to collect primary data from 15 December, 2017 to 25 March, 2018. Data was collected from the respondents by used structured interview schedule and conducting FGD (Focus Group Discussion) for group information.

\section{Preparation of the survey schedule}

In conformity with the objectives of the study, a preliminary survey questionnaire was designed for recording data from the farmers. After pre-testing the questionnaire, necessary corrections, modifications and adjustments were made. The questionnaire was then finalized and questions were arranged in logical sequences so that the farmers could answer the questions easily.

\section{Collection of data}

After development of the final schedule face-to-face interviews were conducted by the researcher herself and some trained enumerators for collection of primary data from the farmers, mostly at the time when they had little works at hand. Before going to make an actual interview, a brief information about the aims and objectives of the present study was clearly explained to the operating farmers and questions were asked systematically in a very simple manner and the information supplied was directly recorded on the interview schedule. It was verified by further visiting to the farmers for fulfilling the lack of information. In order to minimize errors, data were collected in local units. However, these local units were later converted into standard units. The secondary data were collected from the Bangladesh Bureau of Statistics (BBS), Population Census reports, Economic Review report, the daily newspapers, DAE, published and unpublished articles, etc.

\section{Data editing and coding}

Data editing and coding were other vital phases of the survey, which was indispensable for data processing. It should be completed before data processing. In case of this survey, coding had been done along with questionnaire development so that the enumerator could easily and accurately mark the right answers. Data editing referred to the activity of checking and cleaning data that had already been collected from the field.

\section{Data processing}

Data processing involved many steps that were very important because it affected survey results according to the involved steps. During data processing following steps had been taken according to Data entry, Appending and Merging files, Data validation (further computer checking, editing, and imputation), Final decision on errors, Completion of data processing and generation of data files, Final documentations, Conversion of data files to another software, Storage of all files.

\section{Data preservation}

After completion of processing, the data had 
been converted to Microsoft Excel format in order to have the print out. Both original and new format had been preserved. The questionnaires had also been filed for safe storage.

\section{Procedure for computation of costs and returns}

\section{Feed cost}

Feed is the most important input for poultry production in terms of cost, and the availability of low-priced, high-quality feeds is critical if poultry production is to remain competitive and continue to grow to meet the demand for animal protein. Cost of big problem. Lack of access to livestock extension service, bad eggs quality, access to credit also was the challenges for native chicken farmers covering 7 percent, 4 percent and 4 percent, respectively.

Based on the results of the study, 38 percent farmers said that supply and availability of improved native chicken chicks need to be improved. Twenty two percent farmers wanted hands on training of scientific management and rearing practice facilities and 20 percent farmers wanted easy access to livestock extension service. Thirteen percent farmers said that medicine and

Access to credit

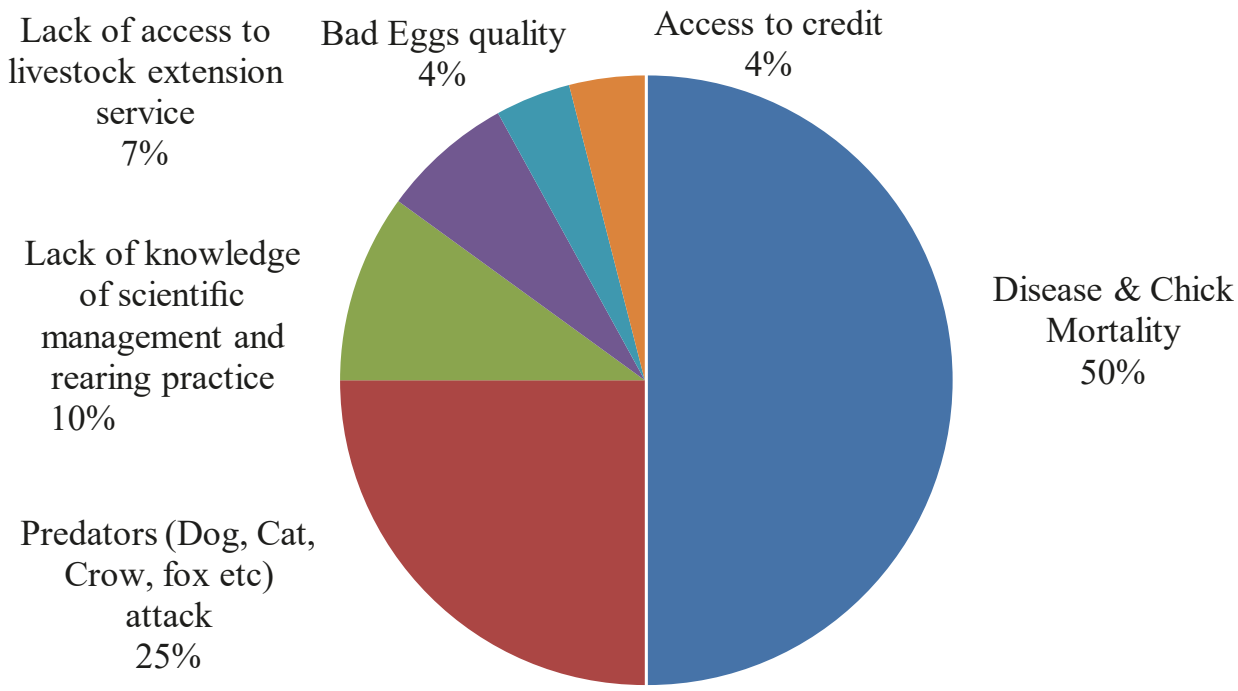

Fig. 1: Problems facing from rearing native chicken

feed included readymade feed, rice polish, wheat bran, crushed maize, fish Based on the results of the study, 50 percent farmers said that their main problem for rearing native chicken was the diseases and chick mortality. Predators (Dog, Cat, Crow, fox etc.) attack holds second position covering 25 percent opinion. Ten percent farmers identified lack of knowledge of scientific management and rearing practice was also a vaccine for native chicken always not available in the market. Interest free livestock credit was wanted by 5 percent of farmers and 2 percent farmers wanted subsidy on poultry feed and other ingredients.

\section{Conclusion and Recommendations}

The importance of rearing native chicken can be categorized into points such as, economic point of view and nutritional point 


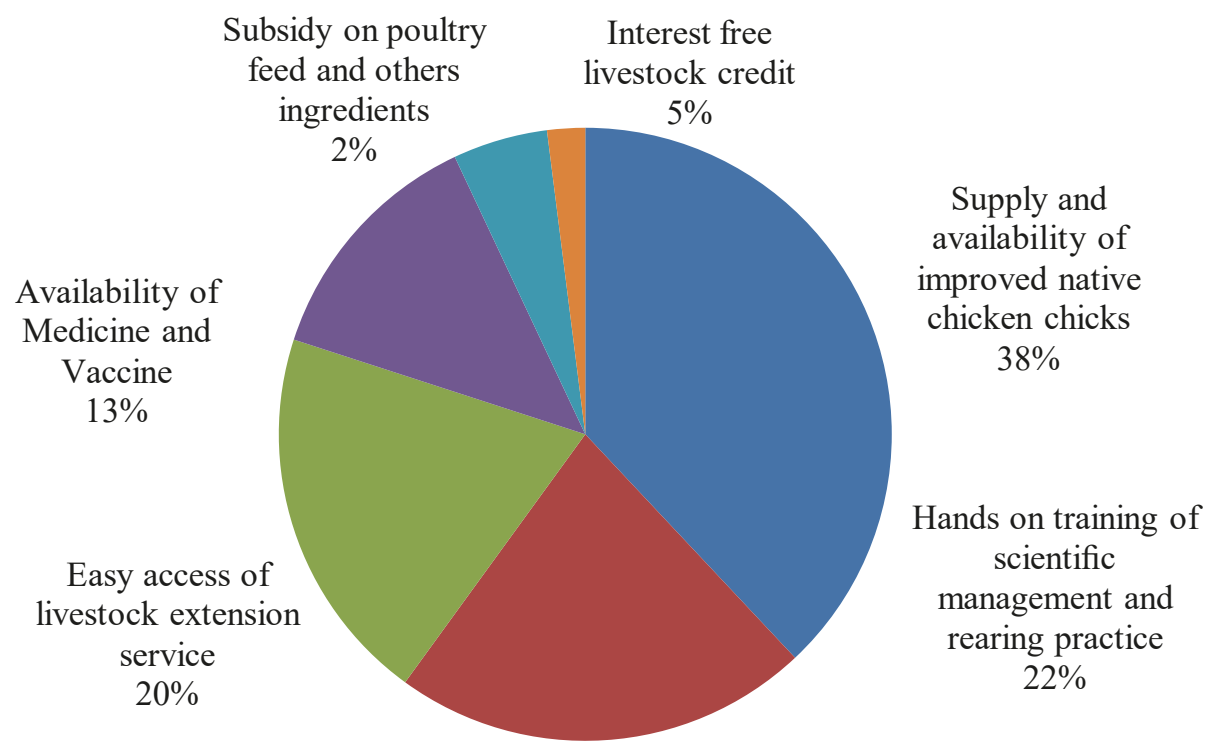

Fig. 2: Farmers opinion to solve the problems

of view. Native chicken would be an important source of rural household income and safe animal protein source. In respect of nutrition, eggs are excellent sources of protein with essential amino acids, carbohydrates, minerals, and fats etc. which are the most nutritious components of human diet. From economic point of view, it is more profitable than other poultry birds. Improved native chicken birds are normally scavenging and laid more eggs than traditional chicken and also market price of both birds are same. In terms of profitability, income, low investment and particularly of women employment generation improved native chicken farming appears to be a promising sub sector. From this study it was cleared that rearing native chicken farming brought positive changes in economic, social and specially women empowerment indicators. The following recommendations are suggested based on the result of the current study: ((i) Local chicken ecotypes were dominant and more adapted for the existing scavenging chicken production system of the district. It is possible to distribute improve native chicken birds to the farmers for higher productivity and income. (ii) There is urgent need for appropriate intervention in diseases and predator control activities so as to reduce mortality and improve productivity of birds. (iii) Control of diseases could be achieved through improvement in veterinary and advisory services. (iv) The problem of predators could be reduced by convincing farmers to construct and housing birds in predator proof separate chicken houses, especially during the night. (v) As most of native chicken production activity is managed by women, provision of successive trainings on modern chicken husbandry practices to women would be essential for the improvement of chicken production and productivity. (vi) Provision of credit facilities to chicken owners and linking the production with marketing will encourage chicken owners and contribute to the improvement of the sector. 


\section{Acknowledgement}

The authors are very grateful to Director General, Bangladesh Livestock Research Institute and Head, Socio-economic Research Division, Bangladesh Livestock Research Institute for providing necessary facilities to conduct the research.

\section{References}

Ajayi, F.O. and Agaviezor, B.O. 2012. Flock size, productivity and management of backyard chicken reared by women in Yenagoa Local Government Area of Bayelsa State. Afri. J. Agri. Tech. and Environ.1 (1): 47-53. BBS. 2018. Bangladesh Bureau of Statistics, Statistics Division, Ministry of Planning, Government of the Peoples' Republic of Bangladesh, Dhaka.

BER 2019. Bangladesh Economic Review, Economic Advisers Wing, Finance Division, Ministry of Finance, Government of the People's Republic of Bangladesh.
Bradley, F.A. 1992. A historical review of women's contributions to poultry production and the implications for poultry development policy. Proceedings of the 19th Wld.'s Poultry Congress, Vol. 2, Amsterdam, The Netherlands. p. $693 \pm 696$.

Uddin, M. T., Islam, M. M., Salam, S. and Yasmin, S. 2013. Economics of native poultry rearing in the coastal regions of Bangladesh. Bang. J. Anim. Sci. 42 (1): 49-56.

Yang, W. Y. 1985. Method of Farm Management Investigation, Food and Agricultural Organization of the United Nation, Rome.

Yang, W.Y., 1965. Methods of Farm Management Investigations for Improving Farm Productivity. Revised Edition. FAO Agricultural Development Paper No 80. Rome, Italy, Rome: Food and Agriculture Organization of the United Nations. 